\begin{tabular}{|c|c|c|}
\hline UAD & Jurnal Cakrawala Promkes & Gounte \\
\hline $\begin{array}{l}\text { Universitas } \\
\text { Ahmad Dahlan }\end{array}$ & $\begin{array}{c}\text { Vol. 3, No. 1, Februari 2021, pp. 17-25 } \\
\text { https://doi.org/10.12928/jcp.v3i1.3583 } \\
\text { http://journal2.uad.ac.id/index.php/cp/index }\end{array}$ & 2 \\
\hline
\end{tabular}

\title{
Pengaruh pemberian konseling terhadap perubahan indeks massa tubuh anak usia 10-12 tahun
}

\author{
Hafifatul Auliya Rahmy a ${ }^{a}$, , Nurul Prativa ${ }^{\mathrm{b}}$ \\ a Prodi Kesehatan Masyarakat UIN SulthanThaha Saifuddin Jambi, \\ b Prodi Kesehatan Masyarakat Universitas Andalas \\ *rahmyhafifatul@gmail.com \\ *Correspondent Author
}

Article history

Received

Revised

Accepted

Keywords

Body Mass Index

Obesity

Nutrition intervention

Counseling

Childhood
Obesity in childhood can increase the incidence of type 2 diabetes mellitus (DM). It is also at risk of becoming obese in adulthood. May cause glucose metabolism disorders and degenerative diseases. Besides, obesity in children aged 6-7 years can also reduce intelligence level due to decreased activity and creativity of children and tend to be lazy due to being overweight. This type of research is a quasiexperimental one-group pre-post-test design. The population in this study were all elementary school students in the work area of Puskesmas Andalas. Body Mass Index (BMI) was collected by measuring height and weight using a digital scale and microtoice. Nutrition counseling using leaflet media. Energy intake data collection before and after counseling used the Food Frequency Questionnaire and the 24-hour recall. The researcher collected characteristics data, physical activity data, body weight data, Body Mass Index data using a questionnaire and analysis of BMI differences before and after the intervention using the dependent sample t-test. The results have a distinction between BMI before and after the intervention. Treatment of obesity in childhood with nutritional balance includes eating various foods, doing physical activity, and regularly monitoring body weight.

This is an open-access article under the CC-BY-SA license.

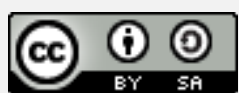

\section{Pendahuluan}

Obesitas adalah istilah untuk berat badan seseorang yang melebihi normal, terjadi akibat ketidakseimbangan antara asupan dan pengeluaran energi (1). Obesitas pada anak dapat meningkatkan kejadian diabetes mellitus (DM) tipe 2. Selain itu, obesitas pada anak juga berisiko untuk menjadi obesitas hingga dewasa, Sehingga berpotensi mengakibatkan gangguan metabolisme glukosa dan penyakit degeneratif seperti penyakit jantung dan penyumbatan pembuluh darah. Selain itu, obesitas pada anak usia 6-7 tahun juga dapat menurunkan tingkat kecerdasan karena aktivitas dan kreativitas anak menjadi menurun dan cenderung malas akibat kelebihan berat badan (2). Penyebab obesitas pada anak adalah pola makan anak yang tidak sehat, mitos salah (anak gemuk adalah anak sehat), dan faktor genetik (10\%). Kelebihan berat badan pada anak bisa jadi pemicu berbagai komplikasi, seperti kadar kolesterol tinggi di dalam darah, tekanan darah tinggi (hipertensi), dan penebalan pembuluh darah jantung (3) (4). Ada beberapa penyakit yang bisa mengakibatkan obesitas pada anak, misalnya sindroma Prader-Willi dan Bardel-Biedl, dua penyakit yang berkaitan dengan fungsi otak, yaitu otak tidak mampu 
memberikan sinyal rasa kenyang (5). Faktor lain penyebab obesitas yaitu kurangnya olahraga. Jadi, sejak masih berusia balita, anak sebaiknya dibiasakan melakukan berbagai aktivitas fisik, seperti bermain, berlari, berenang, dan olahraga lainnya (6) (7).

Prevalensi gemuk pada anak umur 5-12 tahun di Indonesia sebesar 18,8 \%, terdiri dari gemuk sebanyak 10,8 \% dan obesitas sebanyak 8,0\% (8). Prevalensi obesitas di Sumatera Barat sebesar 19,1 \% dengan persentase gemuk 11,4\% dan obesitas 7,7\% (9). Data hasil Penilaian Status Gizi (PSG) 2017 menunjukkan prevalensi gemuk pada anak balita di Kota Padang sebesar 3,8\% (10). Berdasarkan data hasil penjaringan terhadap anak sekolah dasar di Provinsi Sumatera Barat tahun 2015, obesitas memiliki prevalensi 1,2\%, dan Kabupaten/Kota yang paling tinggi angka obesitasnya adalah Kota Padang 2,9\%, Kabupaten Pesisir Selatan 2,9\%, Kota Padang Panjang 1,9\%, Kota Solok 1,9\%, dan Kabupaten Padang Pariaman 1,8\% (11). Di Kota Padang yang paling tinggi kejadian obesitasnya di wilayah kerja Puskesmas Andalas yaitu 6,1\%. Sekolah Dasar yang paling tinggi kasus obesitas adalah SD Negeri 30 (20,8\%), SD Kartika I-10 (16,4\%), dan SD Budi Mulya $(10,4 \%)(12)$.

Mengatasi obesitas pada anak dan remaja bertujuan untuk mencapai berat badan yang ideal dan pengurangan IMT secara aman dan efektif serta mampu mencegah komplikasi jangka panjang akibat obesitas seperti, diabetes mellitus, hipertensi dan penyakit kardiovaskuler. Kompleksnya permasalahan obesitas pada anak perlu ditangani bersama antara dokter anak, psikolog, ahli gizi, tenaga kesehatan lainnya dan tentu saja orang tua. Anak sedang dalam masa pertumbuhan maka pemantauan berat badan secara berkala sangat dianjurkan, menurunkan berat badan anak harus dilakukan dengan perhitungan yang tepat agar tidak mengganggu pertumbuhanya (13). Prinsip tata laksana gizi lebih dan obesitas pada anak adalah menerapkan pola makan sehat, aktivitas fisik yang benar, dan modifikasi perilaku dengan orangtua sebagai panutan. Diet berhubungan dengan makanan yang dikonsumsi dalam keluarga sehari-hari maka partisipasi seluruh anggota keluarga untuk ikut mengubah pola makanan akan sangat bermanfaat. Kurangi konsumsi makanan cepat saji dan banyak mengandung lemak terutama asam lemak tak jenuh dan mengurangi makanan yang manis-manis (14) (15).

Menurut Anam (2010), penurunan indeks massa tubuh pada anak obesitas setelah dilakukan intervensi diet dan olahraga selama 8 minggu. Intervensi diet yang dilakukan dengan cara konseling terhadap subyek dan orangtua pada penelitian ini berhasil menurunkan asupan kalori harian subyek penelitian dari rata-rata $1923 \mathrm{kkal} / \mathrm{hari}$ menjadi $1502 \mathrm{kkal} / \mathrm{hari}$ atau sekitar 420 kkal/hari. Asupan diet pada awal penelitian mendapatkan rerata asupan harian yang tinggi dengan rerata yang dianjurkan untuk kelompok umur dan berat badan pada subyek sekitar 1600 -1800 kkal/hari (16) (17) (18). Konseling yang intensif dan terstruktur dapat membantu klien dalam mengubah perilaku makan. Konseling gizi yang dilakukan terhadap anak overweight dan obesitas diharapkan dapat merubah pola dan kebiasaan makan yang tinggi energi, tinggi lemak jenuh dan rendah konsumsi serat, serta meningkatkan aktifitas fisik (19) (20). Penelitian ini bertujuan untuk melihat perubahan IMT sebelum dan sesudah intervensi melalui konseling pada anak sekolah yang mengalami obesitas.

\section{Metode}

Penelitian ini bersifat quasi eksperiment one group pre-post-test design. Intervensi dalam bentuk pemberian konseling pada anak obesitas. Lokasi penelitian dilakukan di Puskesmas Andalas. Populasi dalam penelitian ini adalah seluruh siswa/i SD Kartika 1-10 dan Sekolah Dasar Negeri 30 di Kota Padang. Sampel adalah anak yang mengalami obesitas dengan kriteria inklusi: bersedia menjadi responden. Kriteria eksklusinya adalah mengalami sakit yang tidak memungkinkannya untuk menjadi sampel penelitian. Berdasarkan hasil skrining terdapat 26 yang mengalami obesitas, namun hanya 20 yang terjaring sebagai responden hingga akhir penelitian. Kegiatan penelitian dimulai dengan skrining melalui pengukuran berat badan dan tinggi badan untuk mendapatkan data Indeks Massa Tubuh (IMT) sebelum pemberian konseling, selanjutnya memberikan inform consent kepada orang tua dan melakukan pengumpulan data riwayat makan 
anak dengan menggunakan form recall $2 \times 24$ jam untuk mendapatkan data asupan energi dan food frequency questionare untuk mendapatkan data pola konsumsi (jenis dan frekuensi konsumsi makanan). Instrumen lain yang juga digunakan adalah kuesioner untuk mendapatkan data karakteristik anak, dan data berat lahir anak, data aktivitas fisik anak dan data orang tua. Pengisian kuesioner diisi oleh anak didampingi oleh orang tua.

Tahap berikutnya dilakukan konseling gizi kepada orang tua selama 6 minggu oleh ahli gizi dengan konseling sebanyak 6 kali pertemuan. Tujuan pemberian konseling agar orang tua dapat memperbaiki pola makan dan pola aktivitas fisik pada anak. Materi yang disampaikan adalah 1) dampak obesitas pada anak, 2) penyebab obesitas, 3) cara menentukan status gizi 4) cara pencegahan dan penanggulangan obesitas, 5) pola makan anak sekolah dan 6) aktivitas fisik. Pemberian konseling dilakukan di sekolah dan kunjungan rumah bagi orang tua yang tidak bisa datang ke sekolah. Media yang digunakan saat konseling adalah leaflet. Tahap akhir penelitian dilakukan pengukuran berat badan dan tinggi badan untuk mendapatkan data IMT setelah pemberian konseling dan riwayat makan dengan menggunakan form recall $2 \times 24$ jam. Pengolahan data meliputi editing, coding, entry dan cleaning. Analisis data yang digunakan adalah uji beda rata-rata dependent samples " $\mathrm{t}$ " test dengan derajat kepercayaan p-value 0,05.

\section{Hasil dan Pembahasan}

Hasil penelitian menunjukkan lebih dari separuh responden berjenis kelamin laki-laki (60\%), mempunyai kebiasaan makan teratur 3 kali sehari yaitu $60 \%$, dan yang memiliki pantangan makanan $25 \%$. Responden tidak mengkonsumsi makanan tertentu karena adanya riwayat alergi terhadap suatu makanan. Diantaranya makanan pantangan adalah susu bubuk, seafood, susu sapi, ikan laut, udang, dan telur. Selain itu, orang tua responden menggunakan cara menggoreng untuk pengolahan makanannya sebanyak $70 \%$, responden yang memiliki kebiasaan sarapan sebanyak $75 \%$, sebagian besar responden jarang mengkonsumsi buah (80\%), responden yang tidak pernah mengkosumsi buah karena tidak suka terdapat $10 \%$. Responden yang mengkonsumsi sayur setiap hari (40\%), responden yang tidak pernah mengkonsumsi sayur karena tidak suka sebanyak $20 \%$.

Penelitian Anzarkusuma (2014) responden yang memiliki frekuensi makan 3 kali dalam sehari sebanyak 53.2\% lebih rendah yaitu, sedangkan memiliki kebiasaan sarapan pagi lebih banyak yaitu sebanyak 94.4\% (21). Selain itu juga pada penelitian Panjaitan (2019) didapatkan 94,2\% memiliki pola makan yang tidak baik (22). Pola makan yang tidak seimbang dapat menimbulkan defisiensi atau kelebihan zat gizi. Konsumsi makanan yang rendah serat seperti jarang mengkonsumsi buah dan sayur dapat meningkatkan risiko terjadinya obesitas. Pada penelitian ini (lihat table 1) dapat dilihat juga 40\% asupan energi melebihi anjuran dan asupan serat $100 \%$ responden kurang. Pada buku Penuntun Diet Anak yang ditulis oleh ASDI, IDAI dan Persagi (2015) Makanan yang dianjurkan pada anak yang mengalami gizi lebih (gemuk dan obesitas) adalah mengkonsumsi sayuran dan serta yang dapat membantu proses penurunan berat badan (23). Menurut ASDI, IDAI dan Persagi (2015) anak yang obesitas ditandai dengan adanya penimbunan lemak yang berlebihan didalam tubuh yang ditandai dengan indikator BB/TB lebih dari $120 \%$ dari median BB/TB (23). Responden pada penelitian ini memiliki gejala fisik yang memiliki timbunan lemak di pipi atau perut sebanyak 65\%. Beberapa pemeriksaan fisik yang perlu diperhatikan pada anak yang obesitas menurut IDAI (2014) adalah diantaranya wajah membulat, pipi tembem, dagu rangkap, leher relatif pendek, dada yang membusung dan perut membuncit (13).

Faktor lainnya yang berhubungan dengan kejadian obesitas pada anak adalah faktor genetik. Menurut Guyton, A.C. dan J.E. Hall (2007) menjelaskan gen dapat berperan dalam obesitas dengan menyebabkan kelainan satu atau lebih saraf yang mengatur pusat makan, kelainan pada pengeluaran energi dan penyimpanan lemak. Ketiga penyebab obesitas monogenik adalah mutasi MCR-4 yang merupakan penyebab monogenik tersering, defisiensi leptin kongenital, dan mutasi reseptor leptin. Gen lain penyebab obesitas yang ditemukan oleh peneliti yaitu gen FTO yang mempengaruhi berapa banyak orang memakan makanan sebelum ia kenyang (24). Pada penelitian ini didapatkan responden yang salah satu orang tua mereka mengalami obesitas 
sebanyak 50\%. Hasil penelitian sudah banyak menunjukkan terdapat hubungan yang bermakna antara status gizi orang tua dengan satus gizi anak. Penelitian Sudiawan dan Sidiartha (2017) menunjukkan bahwa orang tua yang obesitas baik ayah atau ibu saja dan keduanya memiliki risiko anak yang juga mengalami obesitas. Risiko overweight/obese lebih tinggi pada anak dengan bapak overweight/obese 2,021 kali, ibu overweight/obese 2,32 kali, dan kedua orangtua overweight/obese 5,882 kali terhadap status gizi anak (25).

Tabel 1. Distribusi Frekuensi Perilaku Makan Responden

\begin{tabular}{|c|c|c|}
\hline Kategori & $\boldsymbol{F}$ & $\%$ \\
\hline \multicolumn{3}{|l|}{ Frekuensi Makan } \\
\hline Tidak 3 Kali makan utama dan 2 selingan & 8 & 40 \\
\hline Ya 3 Kali makan utama dan 2 selingan & 12 & 60 \\
\hline \multicolumn{3}{|l|}{ Pantangan Makan } \\
\hline Ada & 5 & 25 \\
\hline Tidak ada & 15 & 75 \\
\hline \multicolumn{3}{|l|}{ Cara Pengolahan } \\
\hline Goreng & 14 & 70 \\
\hline Goreng \& gulai & 2 & 10 \\
\hline Goreng \& bakar & 1 & 5 \\
\hline Goreng \& gulai \& bakar & 1 & 5 \\
\hline Goreng \& gulai \& kukus & 1 & 5 \\
\hline Goreng \& gulai \& tumis \& rebus & 1 & 5 \\
\hline \multicolumn{3}{|l|}{ Konsumsi Buah } \\
\hline Tidak pernah & 2 & 10 \\
\hline Jarang (1-3x/minggu) & 16 & 80 \\
\hline Selalu (Setiap hari) & 2 & 10 \\
\hline \multicolumn{3}{|l|}{ Konsumsi Sayur } \\
\hline Tidak pernah & 4 & 20 \\
\hline Jarang (1-3x/minggu) & 8 & 40 \\
\hline Selalu (setiap hari)) & 8 & 40 \\
\hline \multicolumn{3}{|l|}{ Tanda Fisik } \\
\hline Ada, timbunan lemak di pipi dan perut & 5 & 25 \\
\hline Ada, timbunan lemak di pipi atau perut & 13 & 65 \\
\hline Tidak ada & 2 & 10 \\
\hline \multicolumn{3}{|l|}{ Orangtua Obesitas } \\
\hline Ya, kedua orang tua & 6 & 30 \\
\hline Ya, salah satu orang tua & 10 & 50 \\
\hline Tidak & 4 & 20 \\
\hline \multicolumn{3}{|l|}{ Olahraga } \\
\hline $1 \mathrm{x} /$ minggu & 3 & 15 \\
\hline $2 \mathrm{x} /$ minggu & 10 & 50 \\
\hline$\geq 3 \mathrm{x} /$ minggu & 7 & 35 \\
\hline \multicolumn{3}{|c|}{ Aktivitas Sedentary (video games, playstation, televisi dan komputer) } \\
\hline$>3$ jam/hari & 8 & 40 \\
\hline $2-3 \mathrm{jam} / \mathrm{hari}$ & 6 & 30 \\
\hline$\leq 1 \mathrm{jam} / \mathrm{hari}$ & 6 & 30 \\
\hline
\end{tabular}

Pada tabel 1 juga diketahui sebanyak setengah responden (50\%) yang memiliki kebiasaan olahraga $2 x$ /minggu dan memiliki lama aktivitas sedentari atau waktu luang $>3$ jam/hari (40\%). Sedentary activity pada penelitian ini dispesifikkan dalam hal jumlah waktu yang dihabiskan untuk waktu luang meliputi: menonton TV, bermain game (Play Station/online game) dan browsing internet. Hasil penelitian ini tidak jauh berbeda dengan penelitian Suryani dkk (2017) didapatkan mayoritas kategori sedentary activity untuk screen time adalah sedang (64.7\%) yaitu 
sekitar 1-3 jam/hari dan 16,2\% anak menonton TV >3 jam/hari (26). Gaya hidup sehari-hari yang tidak membutuhkan pengeluaran energy yang banyak merupakan ancaman utama bagi individu yang tidak ingin mengalami kelebihan berat badan. Berat badan berlebih pada anak tidak hanya diakibatkan terlalu banyak makanan yang dikonsumsinya sehari-hari, tetapi juga karena kurangnya aktivitas fisik. Pada penelitian ini dapat dilihat sebanyak $40 \%$ anak memiliki frekuensi melakukan aktivitas sedentary seperti menonton televisi, main game, playstation dan komputer > 3 jam / hari. Hal ini menunjukkan bahwa responden pada penelitian ini memiliki gaya hidup kurang aktivitas fisik. Hasil ini lebih rendah dari penelitian Andini (2016) dengan jumlah anak obesitas yang melakukan aktivitas sedentary lebih dari 3 jam / hari adalah sebesar 50\% (27).

Tabel 2. Rata-rata Berat Lahir Responden

\begin{tabular}{ccccc}
\hline Variabel & Mean & SD & Min & Maks \\
\hline Berat lahir $(\mathrm{Kg})$ & 3,4 & 0,6 & 2,3 & 4,7 \\
\hline
\end{tabular}

Faktor lain yang juga berhubungan dengan kejadian obesitas pada anak adalah berat lahir, untuk rata-rata berat lahir dapat dilihat di table 2 . Hasil penelitian menemukan rata-rata berat lahir responden 3,4 kg. Berat lahir paling rendah adalah 2,3 kg dan tertinggi 4,2 kg. Pada pedoman Gentas menurut Kemnkes RI (2017) riwayat berat saat lahir memiliki hubungan yang positif dengan obesitas saat masa anak-anak dan saat ia dewasa. Anak yang saat lahir memiliki berat badan kurang dan berat badan lebih dari normal, berisiko mengalami obesitas setelah ia dewasa (1). Hal ini sama dengan penelitian Zou Z (2019) mendapatkan bahwa berat lahir anak berhubungan dengan kejadian gizi lebih dan obesitas pada anak dan remaja (28).

Tabel 3. Perbedaan Nilai Antropometri dan Asupan Sebelum dan Sesudah Intervensi

\begin{tabular}{|c|c|c|c|c|c|c|c|c|c|c|}
\hline \multirow[t]{2}{*}{ Kategori } & \multicolumn{3}{|c|}{ Mean } & \multicolumn{2}{|c|}{$S D$} & \multicolumn{2}{|c|}{ Min } & \multicolumn{2}{|c|}{ Maks } & \multirow{3}{*}{$\begin{array}{c}p \text { - } \\
\text { Value }\end{array}$} \\
\hline & pre & post & selisih & pre & post & pre & post & pre & post & \\
\hline \multicolumn{10}{|l|}{ Antropometri } & \\
\hline $\begin{array}{l}\text { Berat Badan } \\
\text { (kg) }\end{array}$ & 44,22 & 45,19 & $-0,97$ & 5,75 & 5,82 & 35,5 & 35,8 & 54,9 & 54,1 & 0,108 \\
\hline $\begin{array}{l}\text { Tinggi } \\
\text { Badan (cm) }\end{array}$ & 137,28 & 137,28 & - & 5,40 & 5,40 & 130,7 & 130,7 & 146,60 & 146,60 & - \\
\hline IMT & 23,39 & 24,4 & $-1,01$ & 2,11 & 2,29 & 19,8 & 20.64 & 29,02 & 29,12 & 0,093 \\
\hline \multicolumn{11}{|l|}{ Asupan } \\
\hline $\begin{array}{l}\text { Energi } \\
\text { (kkal) }\end{array}$ & 1581,4 & 2175,4 & -594 & 342,84 & 597,64 & 1002,7 & 1007,70 & 2203,25 & 3126,0 & 0,603 \\
\hline $\begin{array}{l}\text { Karbohidrat } \\
\text { (gr) }\end{array}$ & 186,7 & 286,4 & $-99,7$ & 47,9 & 120,65 & 104,65 & 84,10 & 294,55 & 496,20 & 0,234 \\
\hline $\begin{array}{l}\text { Protein } \\
\text { (gr)* }\end{array}$ & 59,47 & 77,80 & $-18,33$ & 18,56 & 26,70 & 30,9 & 26,6 & 90,3 & 131,3 & 0,017 \\
\hline Lemak (gr) & 64,3 & 79,82 & $-15,52$ & 20,26 & 34,48 & 41,8 & 30,70 & 119,25 & 161,20 & 0,056 \\
\hline Serat (gr) & 6,18 & 8,46 & $-2,28$ & 2,28 & 9,29 & 2 & 2,4 & 10,8 & 35,10 & 0,281 \\
\hline
\end{tabular}

Pada table 3. rata-rata berat badan responden sebelum dilakukan intervensi adalah 44,22 kg dan setelah intervensi 45,19 kg. Rata-rata tinggi badan responden $137,28 \mathrm{~cm}$. Berat badan ideal berdasarkan AGK Kemenkes RI (2019) untuk anak laki-laki usia 10-12 tahun adalah $36 \mathrm{~kg}$ dan perempuan $38 \mathrm{~kg}$ (21). Setelah didapatkan data berat badan dan tinggi badan maka dihitung IMT responden. Rata-rata IMT responden sama setelah pengukuran sebelum $23,39 \mathrm{~kg} / \mathrm{m}^{2}$ dan sesudah intervensi $24,4 \mathrm{~kg} / \mathrm{m}^{2}$. Berdasarkan hasil uji statistik diperoleh p value 0,093 , secara statistic tidak ada perbedaan yang signifikan pada IMT responden sebelum dan sesudah intervensi. Artinya tidak ada pengaruh perlakuan konseling terhadap responden. Hal ini dapat disebabkan karena jumlah sampel yang diteliti hanya 20 orang serta lama intervensi yang dilakukan selama 6 minggu. Ini 
menjadi keterbatasan pada penelitian ini. Pada penelitian yang dilakukan oleh Oktaria (2020) dengan melakukan metaanalisis upaya pencegahan obesitas pada anak usia sekolah menemukan bahwa melalui intervensi pendidikan gizi dan aktivitas fisik berbasis sekolah didapat lama intervensi yang paling pendek untuk mendapatkan perubahan IMT pada anak sekolah adalah selama 2 bulan atau 8 minggu (29).

Anjuran konsumsi zat gizi menurut AKG yang ditetapkan Kemenkes RI (2019) untuk asupan energi usia anak 10-12 tahun untuk jenis kelamin laki-laki adalah 2000 kkal per hari dan 1900 kkal per hari untuk perempuan. Anjuran konsumsi karbohidrat 300 gram per hari untuk laki-laki dan 280 geam per hari untuk perempuan, anjuran konsumsi protein 50 gram per hari pada lakilaki dan 55 gram per hari untuk perempuan, anjuran komsumsi lemak untuk laki-laki dan perempuan sama yaitu 65 gram per hari dan anjuran konsumsi serta pada laki-laki 28 gram per hari dan perempuan 27 gram perhari (21).

Tabel 4. Distribusi Frekuensi Asupan Berdasarkan Angka Kecukupan Gizi

\begin{tabular}{|c|c|c|c|c|c|}
\hline \multicolumn{3}{|l|}{ Sebelum Intervensi } & \multicolumn{3}{|l|}{ Setelah Intervensi } \\
\hline & $f$ & $\%$ & & $f$ & $\%$ \\
\hline Energi & & & Energi & & \\
\hline Lebih (>110\% AKG) & 8 & 40 & Lebih (>110\% AKG) & 6 & 30 \\
\hline Cukup (80-110\% AKG) & 12 & 60 & Cukup (80-110\% AKG) & 14 & 70 \\
\hline Karbohidrat & & & Karbohidrat & & \\
\hline Lebih (>110\% AKG) & 2 & 10 & Lebih (>110\% AKG) & 9 & 45 \\
\hline Cukup (80-110\% AKG) & 18 & 90 & Cukup (80-110\% AKG) & 11 & 55 \\
\hline Protein & & & Protein & & \\
\hline Lebih (>110\% AKG) & 11 & 55 & Lebih (>110\% AKG) & 17 & 85 \\
\hline Cukup (80-110\% AKG) & 9 & 45 & Cukup (80-110\% AKG) & 3 & 15 \\
\hline Lemak & & & Lemak & & \\
\hline Lebih (>110\% AKG) & 13 & 65 & Lebih (>110\% AKG) & 12 & 60 \\
\hline Cukup (80-110\% AKG) & 7 & 32 & Cukup (80-110\% AKG) & 8 & 40 \\
\hline Serat & & & Serat & & \\
\hline Kurang $(<80 \%$ AKG) & 20 & 100 & Kurang $(<80 \%$ AKG) & 19 & 95 \\
\hline & & & Cukup & 1 & $5 \%$ \\
\hline
\end{tabular}

Berdasarkan tabel 4 dapat dilihat terdapat anak sekolah yang memiliki asupan zat gizi yang terdiri dari 30\% memiliki asupan energi berlebih, 45\% asupan karbohidrat berlebih, $85 \%$ asupan protein berlebih dan $60 \%$ memiliki asupan lemak yang berlebih dari anjuran. Sedangkan untuk asupan serat sebelum intervensi semua anak memiliki asupan serat yang kurang dan setelah intervensi terdapat 5\% yang sudah memiliki cukup asupan serat. Pada penelitian Sarwa (2018) asupan energi yang melebihi anjuran $>2000$ kkal berhubungan dengan kejadian obesitas pada anak sekolah (30). Menurut IDAI (2014) upaya pencegahan dan penanggulangan obesitas pada anak dapat dilakukan dengan terjadinya perubahan pola dan perilaku makan meliputi meningkatkan kebiasaan konsumsi buah dan sayur, mengurangi konsumsi makanan dan minuman manis, mengurangi konsumsi makanan tinggi energi dan lemak, mengurangi konsumsi junk food, serta peningkatan aktivitas fisik dan mengurangi sedentary life style (11) (31). Berdasarkan hasil penelitian yang dilakukan oleh Sari dkk (2019) diketahui intervensi yang paling efektif dan sering dilakukan untuk pencegahan obesitas adalah adalah dengan mengubah budaya hidup yang tidak sehat terkait dengan pola makan dan aktifitas fisik dalam lingkungan keluarga. Oleh karena itu, diperlukan adanya dukungan dan motivasi keluarga terutama orang tua untuk melakukan kegiatan pencegahan dan intervensi terkait obesitas. Pentingnya peran keluarga, terutama peran orang tua, dapat mencegah timbulnya kasus obesitas sejak dini (32) (33). Senada dengan kajian tersebut, Oktaria, dkk juga menyatakan bahwa intervensi terhadap aktivitas fisik dan pendidikan gizi di lingkungan sekolah juga memberikan pengaruh terhadap penanggulangan obsetias pada anak-anak usia sekolah (34). 
Konseling gizi menurut Kemenkes (2018) bertujuan membantu klien dalam upaya mengubah perilaku yang berkaitan dengan gizi sehingga dapat meningkatkan kualitas gizi dan kesehatan klien, meliputi perubahan pengetahuan, perubahan sikap dan perubahan tindakan. Namun perubahan perlaku seperti yang diinginkan pada penelitian ini adalah adanya penerapan pola makan dengan gizi seimbang, peningkatan aktivitas fisik sehingga nanti dapat nempengaruhi berat badan anak tidak dapat dilakukan dalam waktu singkat. Tujuan pendidikan kesehatan adalah terjadinya perubahan perilaku dari tidak tahu menjadi tahu, dari tidak mau menjadi mau, dari tidak mampu menjadi mampu (35) (36). Untuk itu sangat diperlukan strategi dalam dalam perubahan perilaku yaitu melalui kekuatan atau dorongan yang kuat dari pemerintah, pemberian informasi secara berkala, dan melalui diskusi serta partisipasi. Untuk itu upaya penanggulangan obesitas pada anak sekolah dapat dilakukan dengan berbagai bentuk intervensi baik berbasis sekolah maupun berbasis keluarga.

\section{Kesimpulan}

Sebagian besar responden mempunyai kebiasaan makan teratur 3 kali sehari yaitu $60 \%$, terdapat $25 \%$ responden yang memiliki pantangan makanan, $100 \%$ orang tua responden menggunakan cara menggoreng untuk pengolahan makanannya, sebagian besar responden memiliki kebiasaan sarapan yaitu $75 \%, 80 \%$ jarang mengkonsumsi buah, $60 \%$ jarang mengkonsumsi sayur, sebagian besar (65\%) secara fisik tampak ada timbunan lemak pada pipi atau perut. Rata-rata berat lahir responden 3,4 kg dengan standar deviasi 0,6 kg dan 40\% responden memiliki lama aktivitas sedentari atau waktu luang $>3$ jam/hari. Selain itu juga terdapat perbedaan berat badan, nilai IMT dan asupan energi sebelum dan sesudah intervensi. Penanggulangan obesitas pada anak dapat dengan penerapan gizi seimbang diantaranya mengonsumsi makanan beragam, melakukan aktivitas fisik dan membatasi aktivitas sedentary seperti menonton TV, bermain komputer, game/ playstation $<2$ jam/ hari serta mengontrol berat badan secara teratur.

\section{Ucapan Terimakasih}

Penulis mengucapkan terimakasih kepada ketua Program Studi Kesehatan Masyarakat UIN SulthanThaha Saifuddin Jambi yang telah mensupport penuh artrikel ini.

\section{Konflik Kepentingan}

Tidak ada konflik kepentingan.

\section{Referensi}

1. Kementerian Kesehatan Republik Indonesia. Panduan Pelaksanaan Gerakan Nusantara Tekan Angka Obesitas (GENTAS). Jakarta: Direktorat Pencegahan dan Pengendalian Penyakit Tidak Menular; 2017.

2. Sartika RAD. Faktor risiko obesitas pada anak 5-15 tahun di Indonesia. Makara Kesehat. 2011;15(1):37-43.

3. Febri AB, Marendra Z. Smart Parents Pandai Mengatur Menu \& Tanggap Saat Anak Sakit. Jakarta: Gagasmedia; 2010.

4. Miko A, AL-Rahmad AH. HUBUNGAN BERAT DAN TINGGI BADAN ORANG TUA DENGAN STATUS GIZI BALITA DI KABUPATEN ACEH BESAR. J Indones Nutr Assoc. 2017;40(1):21-34.

5. Pusat Data dan Analisa Tempo. Seri I Mengenal Obesitas pada Anak. Jakarta: Tempo Publishing; 2019. 
6. Soenardi T. 100 Resep Makanan Sehat imhik Anak agar Terhindar Penyakit Degeneratif saat Dewasa. Jakarta: Gramedia Pustaka Utama; 2011.

7. Ishak $\mathrm{S}$, Hatta $\mathrm{H}$, Hadi AJ. HUBUNGAN POLA MAKAN, KETERPAPARAN MEDIA DAN KETURUNAN TERHADAP KELEBIHAN BERAT BADAN PADA SISWA SEKOLAH DASAR The Relationship of Dietary Habit , Media Exposure And Heredity To Over- weight In Elementary School Students. Promot J Kesehat Masy. 2019;9(1):76-84.

8. Wiradyani L, Pramesthi I, Raiyan M, Nuraliffah S, Nurjanatun. Gizi dan Kesehatan Anak Usia Sekolah Dasar. Jakarta: SEAMEO RECFON; 2016.

9. Badan Penelitian dan Pengembangan Kesehatan Depkes RI. Riset Kesehatan Dasar (Riskesdas) 2013. Jakarta: Badan Penelitian dan Pengembangan Kesehatan Departemen Kesehatan Republik Indonesia; 2013.

10. Direktorat Jenderal Kesehatan Masyarakat Kementerian Kesehatan RI. Buku Saku Pemantauan Status Gizi Tahun 2017. Jakarta: Direktorat Gizi Masyarakat; 2018.

11. Dinas Kesehatan Kota Padang. Laporan Penjaringan Per Kab/Kota Tahun 2015. Padang: Dinas Kesehatan Kota Padang; 2015.

12. Sumbar DK. Laporan Penjaringan Per Kab/Kota Tahun 2015 Padang. Sumatera Barat: Dinas Kesehatan Provinsi Sumatera Barat; 2015.

13. IDAI. Diagnosis, Tata Laksana Dan Pencegahan Obesitas Pada Anak Dan Remaja. Jakarta: Ukk Nutrisi Dan Penyakit Metabolik; 2014.

14. Kementerian Kesehatan Republik Indonesia. Pedoman Pencegahan Dan Penanggulangan Kegemukan Dan Obesitas Pada Anak Sekolah. Jakarta: Direktorat Jendral Bina Gizi Dan Kesehatan Ibu Dan Anak Kementerian Kesehatan RI; 2012.

15. Ratnawati D, Sahar J, Permatasari H. PROGRAM LANSET DM SEBAGAI STRATEGI INTERVENSI DIABETES MELITUS PADA LANSIA. Bina Didya. 2015;26(1):6-17.

16. Anam MS, Mexitalia M, Widjanarko B, Pramono A, Susanto H, Subagio HW. Pengaruh Intervensi Diet dan Olah Raga Terhadap Indeks Massa Tubuh, Lemak Tubuh, dan Kesegaran Jasmani pada Anak Obes. Sari Pediatr. 2016;12(1):36-41.

17. Susanti RW, Indriastuti D. Faktor-Faktor yang Berhubungan dengan Penggunaan Complementary And Alternative Medicine ( CAM ) pada Pasien Diabetes Melitus di Puskesmas Poasia Kota Kendari. J Kesehat Andalas. 2020;9(2):174-81.

18. Putri RM, H WR, Maemunah N. KAITAN PENDIDIKAN, PEKERJAAN ORANG TUA DENGAN STATUS GIZI ANAK PRA SEKOLAH. J Care. 2017;5(2):231-45.

19. Sukraniti D, Taufiqurrahman, Iwan S. Bahan Ajar: Konseling Gizi. Jakarta: BPPSDMK Kemenkes RI; 2018.

20. Hadi AJ, Manggabarani S, R EY, Tombeg Z, Ishak S, Said I. Consumption Pattern and Nutrition Conseling Roles on Obesity of Integrated Primary School Students Anto. Unnes J Public Heal. 2019;8(1):45-50.

21. Kementerian Kesehatan Republik Indonesia. Permenkes RI No.28 Tahun 2019 tentang Angka Kecukupan Gizi yang Dianjurkan untuk Masyarakat Indonesia. Jakarta: Kemenkes RI; 2019.

22. Panjaitan WF, Siagian M, Hartono H. Hubungan Pola Makan dengan Status Gizi Pada Anak Sekolah Dasar Al Hidayah Terpadu Medan Tembung. J Dunia Gizi. 2019;2(2):71-8.

23. ASDI, IDAI, PERSAGI. Penuntun Diet Anak. Jakarta: Fakultas Kedokteran Uvinersitas Indonesia; 2015.

24. Guyton AC, Hall JE. Buku Ajar Fisiologi Kedokteran. Jakarta: EGC; 2007.

25. Sudiawan KD, Sidiartha IGL. Hubungan Status Gizi Orangtua Terhadap Status Gizi Anak. E- 
Jurnal Med Udayana. 2017;6(6).

26. Suryani D, Sabrina Y, Cholidah R, Ekawanti A, Andari MY. Studi Status Gizi, Pola Makan serta Aktivitas pada Anak Sekolah Dasar di Kota Mataram. J Kedokt. 2017;6(1):14-9.

27. Andini AR, Aditiawati, Septadina IS. Pengaruh Faktor Keturunan dan Gaya Hidup Terhadap Obesitas pada Murid SD Swasta di Kecamatan Ilir Timur 1 Palembang. J Kedokt dan Kesehat. 2016;3(2):114-9.

28. Zou Z, Yang Z, Yang Z, Wang X, Gao D, Dong Y, et al. Association of high birth weight with overweight and obesity in Chinese students aged 6-18 years: a national, cross-sectional study in China. BMJ Open. 2019;9(5):e024532.

29. Oktaria R, Neherta M, Deswita. Upaya Pencegahan Obesitas Pada Anak Usia Sekolah Melalui Intervensi Pendidikan Gizi Dan Aktivitas Fisik Berbasis Sekolah. J Ilm Permas J Ilm STIKES Kendal. 2020;10(4):599-614.

30. Sarwa, Prasetyo A. Determinant Of Obesity In School - Age Children (Studi di SD Al-Irsyad 0102 Cilacap Tahun 2018). Tens Trends Nurs Sci. 2020;1(1):46-50.

31. Rohmah M, Hidayati K. PROGRAM INDONESIA SEHAT BERBASIS KELUARGA: KONTRIBUSI MODAL SOSIAL KEAGAMAAN DI MASYARAKAT. J Penelit Islam. 2019;13(02):233-50.

32. Sari IP, Anggraini K, Kurniati V, Nurcandra F. Intervensi Obesitas Berbasis Keluarga. J Ilm Kesehat Masy Media Komun Komunitas Kesehat Masy. 2019;11(3):254-61.

33. Mulyono S, Permatasari H. Edukasi sebaya terhadap praktik gizi dan indeks massa tubuh anak usia sekolah yang mengalami gizi lebih. Heal Tadulako J. 2019;5(3):55-63.

34. Oktaria R, Neherta M, Deswita. Upaya pencegahan obesitas pada anak usia sekolah melalui intervensi pendidikan gizi dan aktivitas fisik berbasis sekolah. J Ilm Permas J Ilm STIKES Kendal. 2020;10(4):599-614.

35. Kementerian Kesehatan Republik Indonesia. Bahan Ajar Konseling Gizi. Pusat Pendidikan Dan Sumber Daya Manusia Kesehatan. Jakarta: Balai Pengembangan dan Pemberdayaan Sumber Daya Manusia Kesehatan; 2018.

36. Lestantina A, Wahyudi A, Yuliantini E, Kesehatan P, Kesehatan K, Jurusan B. Konseling gizi pada remaja obesitas. J Media Kesehat. 2018;11(1):71-8. 